\title{
Cooperative Learning Strategy in "EANLIC Class" and Students' Development
}

\author{
Zhiling Chen ${ }^{1}$, Yu Rong ${ }^{2}$ \\ 1,2 Lijiang Teachers College, Lijiang, 674199, China
}

Keywords: Oral english, Cooperative learning, Development.

\begin{abstract}
In oral English teaching, cooperative learning can improve the atmosphere in class and arouse students' learning enthusiasm. This learning strategy can not only improve students' language application ability, but also can help students form good character. This paper is to explore the cooperative strategy in oral English learning and its function of promoting the all-round development of vocational students.

\section{Introduction}

The fundamental objective of Language learning is to communicate with this language. For many years, the popular style of oral English teaching in universities nationwide is still mainly to pass on knowledge of language, resulting in students can't understand or speak out even after many-years study of English. Cooperative learning mode is proposed as an education activity to emphasize equality and cooperation. It provides students with more opportunities to practice oral English and plays a significant role in cultivating with outstanding properties.
\end{abstract}

\section{Cooperative Learning}

Cooperative learning, charactering basically with interpersonal cooperation and interaction, has been booming since early 70s of 20th Century in USA. Considered as a creative and practical teaching theory and strategy, great number of researches on cooperative mode has been developing both domestically and overseas. Cooperation learning are divided into seven basic modes, respectively competition, debate, cooperation, problem-solving, partner, design and role-playing, in Zhao Jianhua, Li Kedong (2000) [1]. Cooperative learning mode is effective and very useful to improve social psychological environment within class, to promote students' academic attainment and to enhance their non-perceive properties, etc. Soon worldwide attraction is drawn on this mode and it becomes one of current main stream of teaching theories and strategies [2]. In recent years, great improvements are obtained in national English Teaching, while cooperative learning, as breakthrough and supplement to traditional teaching methods, has been utilized by English teachers widely in their student-oriented classes to improve students' English scores and to cultivate their properties.

\section{EANLIC Curriculum and Cooperative Learning Around Classes}

EANLIC (English Acquired as a 'Native' Language In China), is a significant language acquisition model proposed by Prof. Duan Pinghua in 2005 in Lijiang Teachers College, Yunnan Province. The heart of this model is to create an English environment within some territorial scope under non-English speaking countries, China for instance, or to manually mimic an English environment among a group of people and then put English learners into this environment for English communication and practice to acquire English [3]. In ENALIC classroom teaching, teachers always utilize the method of group cooperation for study, and oral English is mostly practiced among cooperative groups. Teachers split students from the class into small cooperative groups, distribute 
the tasks to each group, let them to prepare carefully. Finally each group will make presentations to all the classmates. Teachers in the whole time play the roles of organizer, director, supervisor and evaluator, etc. The main work of teacher is to supervise and help each group to fulfill relative work. The most popular cooperative learning activities in EANLC class teaching are respectively Pair Work, Group Discussion, Debate in Class, English Noon Chat, EANLIC Night and Drama Competition.

\section{Research Objectives and Procedure}

This research lasts almost two years, and objectives are students major in Foreign Language in Lijiang Teachers College. Research methods are mainly surveys (questionnaire, visit, actions observation in classes, observation on students participating in English Night activity, literature search and attending a lecture, etc.). The whole research concentrates on whether and to what degree cooperative study application around classes will promote students to comprehensive development.

\section{Research Procedure of Applying Cooperative Learning in EANLIC Class}

Pair Work, Group Discussion, Debate are the methods of cooperative learning used frequently in EANLIC class.

\section{Pair Work}

Materials for EANLIC class are Creative English Creative Communication selected from Shanghai Foreign Language Education Press. One dialogue is designed in each unit of this book which provides two-person cooperative learning mode most frequently in class. Including unit dialogue practices, this method is also used for self-arranging dialogues and small-scale discussion based on teaching contents.

\section{Group Discussion}

In class of EANLIC, issues discussion always uses the mode of group discussion. Culture Corner and Creative Speaking provided in material are all suitable for this method. During discussion, each group leader takes notes on group discussion content. After group discussion, teacher will choose one or two students randomly to report the discussion, and other members make supplement. There are 3 to 5 persons in a group normally. Teacher can make groups according to their characteristics and levels, or let them group freely.

Debate in class

It is to use debate in class for some units of EANLC will generate outstanding teaching effect. Take Unit 9 in second book, "Discussing beliefs about ghosts and the supernatural" for instance. Teacher can split the whole class into three cooperative groups respectively are believe in, disbelieve in, and half-believe in, based on what they are believing in exist of ghosts and the supernatural. All the members in different groups will argue in the debate, presenting their points and practices to preserve their groups. The issues of debate in class shall be interests or enjoyments for students. During the debate, one member will write the points down and use them in final summary. The teacher will master debate in class, to avoid distractions or conflicts when students try to preserve their points.

\section{Research Procedure of Applying Cooperative Learning out of EANLIC Class}

\section{English Noon Chat}

In EANLC language acquisition mode, English day is every Thursday. This means all the teachers and students in foreign language major will communicate in English for that day. Particularly, teachers and students will gather together in the noon for one hour English noon chat. Lecturers will provide students several topics for reference and at noon, students can participate into the groups that fascinating them, sharing the topics from different EANLC lecturers. During the whole activity, students proceed in cooperative study actively and are not restricted from classes.

\section{EANLIC Night}

EANLC Night is a group cooperative learning at English Day at night, lasting for one and a half hours. It is to consolidate acquired oral English. Each class must hold an EANLIC party in their 
classroom and the party will be held by different groups. Group members shall spend quite a period to prepare for the party: discussion on party content, searching for literature, the style of organization, roles of toastmasters, etc. Finally at the party, they will exhibit all the activities to the class.

\section{Drama Competition}

Large scale English drama shows every term and small drama competitions organized outside the class are all the supplementation after EANLIC. Students will cooperate during the whole procedure, from reference searching, material integration, scenario composition, property preparation, roles assignment till rehearsal.

Students are embraced by cooperation no matter in the class or outside the class in EANLIC teaching class. The oral English score of a student is not only dependent on their performance, but also the one's group score in proportion in one's final score. Therefore, students will have group consciousness and their performance will not separate from the whole group.

\section{Research Results and Analysis}

After over one year practice of cooperative learning in Lijiang Teachers College with EANLIC teaching, researchers make analysis on 80 valid questionnaires focusing on students and visit results. The analysis results show that students all acquire improvements in both oral English and non-perceive properties after applying cooperative learning effectively into oral English teaching. Research results are listed in the table below:

Table 1. Cooperative learning Effectiveness to students' properties and percentage

\begin{tabular}{|c|c|c|c|c|c|}
\hline Content & $\begin{array}{l}\text { Outstanding } \\
\text { Improvement }\end{array}$ & $\begin{array}{c}\text { Great } \\
\text { Improvement }\end{array}$ & $\begin{array}{c}\text { Some } \\
\text { Improvement }\end{array}$ & $\begin{array}{c}\text { No } \\
\text { Improvement }\end{array}$ & Lower down \\
\hline $\begin{array}{l}1 \text { Interests in Learning } \\
\text { English } \\
\end{array}$ & 15 p (18.8\%) & 25 p (31.3\%) & 35 p (43.8\%) & $3 \mathrm{p}(3.8 \%)$ & 2 p (2.5\%) \\
\hline $\begin{array}{c}2 \text { Ability of Oral English } \\
\text { Expression }\end{array}$ & 15 p (18.8\%) & 25 p (31.3\%) & 25 р (31.3\%) & 10 p (12.5\%) & 5 p (6.3\%) \\
\hline 3 Learning Initiative & 20 p (25\%) & 25 p (31.3\%) & $20 \mathrm{p}(25 \%)$ & $10 \mathrm{p}(12.5 \%)$ & 5 p (6.3\%) \\
\hline 4 Ability of Self-Learning & 25 р (31.3\%) & 25 p (31.3\%) & 25 р (31.3\%) & $3 \mathrm{p}(3.8 \%)$ & $2 \mathrm{p}(2.5 \%)$ \\
\hline 5 Group Consciousness & 22 p (27.5\%) & 25 p (31.3\%) & 25 p (31.3\%) & $5 \mathrm{p}(6.3 \%)$ & $3 \mathrm{p}(3.8 \%)$ \\
\hline $\begin{array}{l}6 \text { Cooperation } \\
\text { Consciousness } \\
\end{array}$ & 20 р (25\%) & 30 p (37.5\%) & 26 р (32.5\%) & $2 \mathrm{p}(2.5 \%)$ & 2 p (2.5\%) \\
\hline 7 Ability of Cooperation & 22 p (27.5\%) & 35 p (43.8\%) & 20 p (25\%) & $2 \mathrm{p}(2.5 \%)$ & $1 \mathrm{p}(1.3 \%)$ \\
\hline 8 Responsibility & 25 p (31.3\%) & 35 p (43.8\%) & 15 p (18.8\%) & $2 \mathrm{p}(2.5 \%)$ & 3 p (3.8\%) \\
\hline 9 Ability to work together & 20 p (25\%) & 30 p (37.5\%) & 26 p (32.5\%) & $3 \mathrm{p}(3.8 \%)$ & $1 \mathrm{p}(1.3 \%)$ \\
\hline 10 Communication Skills & 22 p (27.5\%) & 30 p (37.5\%) & $25 \mathrm{p}(31.3 \%)$ & $2 \mathrm{p}(2.5 \%)$ & $1 \mathrm{p}(1.3 \%)$ \\
\hline $\begin{array}{l}11 \text { Ability of Active } \\
\text { Participation }\end{array}$ & 20 р (25\%) & 35 p (43.8\%) & 20 р (25\%) & $2 \mathrm{p}(2.5 \%)$ & 3 p (3.8\%) \\
\hline $\begin{array}{c}12 \text { Ability of Active } \\
\text { Practice }\end{array}$ & 25 р (31.3\%) & 23 р (28.9\%) & 25 p (31.3\%) & $2 \mathrm{p}(2.5 \%)$ & 5 p (6.3\%) \\
\hline $\begin{array}{c}13 \text { Ability of Independent } \\
\text { Thinking }\end{array}$ & 22 p (27.5\%) & 25 p (31.3\%) & 25 p (31.3\%) & 5 p (6.3\%) & 3 p (3.8\%) \\
\hline 14 Understanding & 20 p (25\%) & 30 р (37.5\%) & 26 р (32.5\%) & $2 \mathrm{p}(2.5 \%)$ & $2 \mathrm{p}(2.5 \%)$ \\
\hline 15 Problem-solving & $22 \mathrm{p}(27.5 \%)$ & 35 p (43.8\%) & 20 p (25\%) & $2 \mathrm{p}(2.5 \%)$ & $1 \mathrm{p}(1.3 \%)$ \\
\hline 16 Creativity & 25 p (31.3\%) & 35 p (43.8\%) & 15 p (18.8\%) & $2 \mathrm{p}(2.5 \%)$ & 3 p (3.8\%) \\
\hline 17 Honest and loyalty & 20 p (25\%) & 25 p (31.3\%) & 25 p (31.3\%) & 8 p (10\%) & 2 p (2.5\%) \\
\hline 18 Self-Confidence & 20 p (25\%) & 30 p (37.5\%) & 20 p (25\%) & $5 \mathrm{p}(6.3 \%)$ & 5 p $(6.3 \%)$ \\
\hline 19 Trouble-Shooting & 20 p (25\%) & 25 p (31.3\%) & $25 \mathrm{p} \mathrm{(31.3 \% )}$ & $8 \mathrm{p} \mathrm{(10 \% )}$ & $2 \mathrm{p}(2.5 \%)$ \\
\hline 20 Comprehensiveness & 20 p (25\%) & 25 p (31.3\%) & 20 p (25\%) & 10 p (12.5\%) & 5 p (6.3\%) \\
\hline
\end{tabular}

From data listed in the table above, to compare the data respectively in 1st and 2nd items, 3rd and 4th items, it is effectively inspiring students' in learning English via cooperative learning, so that the 
ability of their oral English is promoted. The data in item of Ability of Oral English Expression shows that 15 persons (18.8\%) are improved distinctively, 25 persons (31.3\%) are improved greatly, 25 persons (31.3\%) are improved a lot and 10 persons (12.5\%) feel they learned nothing, while only 5 persons (6.3\%) feel they are lowered down. In general, large-scale application of cooperative learning in oral English teaching helps improve students oral English to a great extent.

From 5th -20th items data, the application of cooperative learning in oral English teaching significantly can help students to form good personalities. According to the item of group consciousness, the effects are respectively 22 persons (27.5\%) of outstanding improvement, 25 persons (31.3\%) of great improvement and 25 persons (31.3\%) of some improvement. Therefore, application of cooperative learning strategy in oral English teaching can cultivate teamwork spirit of students. 9th and 10th items indicate that when students are in cooperative learning, the cooperative consciousness can help them to acquire excellent communication and cooperation skills. During cooperative learning, all the group members will take responsible to sub-tasks which require students to participate in and practice actively and furthermore to take charge in one's role in groups. From data in item 11 and 12, embedded cooperative learning in oral English teaching effectively can cultivate students with abilities of participation and practice and can enhance their responsibility. From data in item 8, the influence on responsibility of students are respectively 25 persons (31.3\%) of outstanding improvement, 35 persons (43.8\%) of great improvement and 15 persons $(18.8 \%)$ of some improvement. Once students are equipped with enthusiasm of cooperation, their activeness will be promoted and they will be enhanced with self-learning. Additionally, during cooperation, it is particularly significant to finish their own sub-task of the group on time and honestly for their common interest. According to 17 th data, $87.6 \%$ of students recognize the significance of honest and loyalty after cooperative learning. According to 17 th data, $87.6 \%$ of students recognize the significance of honest and loyalty after cooperative learning. In this period, students find the problems initiatively and solve them, so that the content brings students confidence. According to 18th data, up to $87.5 \%$ of students thought cooperative learning can help them to improve their confidence. From the data in last item, cooperative learning can definitely improve the comprehensive abilities of students, respectively 20 persons (25\%) of outstanding improvement, 25 persons (31.3\%) of great improvement and 20 persons (25\%) of some improvement while only $18.9 \%$ of students keep opposite opinions.

\section{Conclusions}

After over one year practice of cooperative learning in Lijiang Teachers College with EANLIC teaching, results indicate that effective operative learning in oral English teaching can not only improve oral English ability of students, but also cultivate their emotional attitudes, enhance their confidence, help them to acquire how to co-work with others and fulfill tasks together, enjoying the happiness from cooperation. During cooperative learning, students are equipped with initiatives and activeness so that their oral English are improved large-scale, promoting them to form well non-perceive personalities. Finally cooperative learning will provide a solid foundation for their future work.

\section{References}

[1] Zhao Jianhua, Li Kedong, Cooperative Learning and Cooperative Learning Mode, China audio-visual Education, 2000, (10).

[2] Wang Tan, Cooperative Learning - Principle and Strategy, Beijing, Xueyuan Press, 2001, 45-90.

[3] Duan Pinghua, Searching for creativity in the Chinese TEFL Context, Higher Education Press, 2007-8.

[4] Ian Smallwood, Li Po Lung, Jin Lixian, Creative English Creative Communication, College English Creative Oral English, Shanghai Foreign Language Education Press, 2007-7. 